\title{
A magyar rendőrség első napilapja: A Rend (1921-1927)
}

\section{ANDROVICZ Gábor ${ }^{1}$}

\begin{abstract}
A rendörségtörténeti kutatások során forrásértékük miatt nem hagyhatók figyelmen kívül a - jellemzően az adott fegyveres testület által felügyelt és kiadott - különbözó szakmai folyóiratok. A két világháború között múködő rendörségi szaklapok első képviselőjének A Rend tekinthető, amely az országossá váló Magyar Királyi Állami Rendőrség kortársaként követte nyomon a testület fejlődését. Szakmai fórumként helyet biztosított a rendőrség belső szervezetét érintő vitáknak, továbbá tevékenyen közremüködött a szakképzés, az értékközvetítés és az előremutató kezdeményezések támogatásában. A tanulmány bemutatja a folyóirat elindításának körülményeit, felépitését, föbb tartalmi jegyeinek formálódását és szerepét a korabeli rendészettudományban.
\end{abstract}

Kulcsszavak: sajtótörténet, szaklap, A Rend, rendőrségtörténet

\section{A magyar rendóri szaksajtó megjelenése}

Az 1867-es kiegyezést követően, a magyarországi sajtó szabaddá válásával és a polgári nyilvánosság létrejöttével jelentek meg a kialakulófélben lévő rendészettudomány szakmai fóruma, a rendőri szaksajtó, valamint a rendőri munka gyakorlati kérdéseivel és problémáival foglalkozó értekezések. Forster József pestvárosi rendbiztos szerkesztésében 1869. július-augusztus folyamán jelent meg az első, teljes egészében magyar nyelvű rendőri szaklap, a Közbiztonság. Az alcíme szerint „rendészeti elméleti és tapasztalati ismereteket terjesztő heti szak-közlöny” célkitűzései között szerepelt, hogy a rendőri testület számára útmutatást nyújtson, mivel „addig a rendőrségi közegeknek nem volt módjuk hivatásuk tanulmányozására”. A szakközlöny hasábjain a friss, újszerû rendőrségi kérdések mellett szakmai vitáknak is helyet adott, továbbá hazai és külföldi - a gyakorlatban is alkalmazható - rendőri tapasztalatokat, a szakmához kapcsolódó híreket, kisebb-nagyobb (olykor folytatásos) szakcikkeket, tárcákat, vagy akár egy-egy érdekesebb bűnesetet is tárgyalt, mindezt „könnyen érthető, érdekfeszítő leírásban, [...] hogy tanulságosak és mulattatók is legyenek”. ${ }^{2}$

\footnotetext{
Androvicz Gábor történész, Nemzeti Közszolgálati Egyetem Rendészettudományi Doktori Iskola, doktorandusz. Gábor Androvicz Historian, University of Public Service Doctoral School of Law Enforcement, PhD student. E-mail: androviczgabor@gmail.com, ORCID: https://orcid.org/0000-0002-3760-9712

2 Abonyi Magdolna: A magyar rendőri szaksajtó kezdetei: a Közbiztonság. Magyar Rendészet, 16. (2016), 6. $156-158$.
} 
Forster József mindösszesen két évfolyamot megélt közlönye szakmai példaként és késztetésként szolgált további rendőrségi folyóiratok megjelenéséhez. Nehéz feladat lenne pontosan felsorolni a II. világháborúig megjelenő rendőri-rendészeti témájú időszaki kiadványokat, ${ }^{3}$ azonban kijelenthető, hogy ezek rövidebb-hosszabb fennállásukkal biztosították a rendőri sajtó folyamatos jelenlétét a magyar rendőri szakirodalomban és művelődésben. Bár a modern rendőrségtörténeti kutatások művelői tudhatnak létezésükről, azonban komoly forrásértékük és értékes tartalmuk ellenére ritkán szerepelnek a tudományos kutatások felhasznált irodalomjegyzékeiben. ${ }^{4} \mathrm{Csep}$ reghy Lajos, a Rendőri Lapok felelős szerkesztője 1895-ben így üzent a jelenkor kutatójának: „Felhívjuk azonban a magyar közrendészet történetének íróját, ha ugyan megszületett már, hogy múvéhez e lapok hasábjain is keressen anyagot. Biztosítjuk, hogy fog találni bőven. Sőt, ha mellőzi őket, nem fog alapos történelmet írni."5 Kriskó Edina tanulmányában a rendőri szaklapok szerepét az alábbiakban foglalja össze: „A sajtó mindenképpen jó terepe a vizsgálódásnak, hiszen amikor szakmai lapok indulnak [...] ott van mögöttük a szándék, hogy alakítsák a szervezetről, a rendőri hivatásról kialakult képet. Tevékenységük célkeresztjében az ismeretterjesztés, a rendőri múködés szakmai színvonalának emelése, identitásformálás és egyfajta közösben osztozás megvalósítása áll.”6

\section{A rendőri szakirodalom helyzete Trianon árnyékában}

A Tanácsköztársaság bukását követően, 1919. augusztus 8-án, a Friedrich-kormány hatalomra kerülését követően kezdődött meg a közigazgatás helyreállítása. Az antant katonai bizottsága ellenőrzés alá vonta a csendőrség és rendőrség újjászervezését, emellett a rendőrség munkáját a megszálló román katonaság is erősen gátolta. ${ }^{7}$ A törvényes állapot helyreállítása után vehette csak kezdetét a rendőrség újjászervezése, mivel azonban a magyar törvényhozás csak 1920-ban kezdte meg működését, erről rendeletileg kellett intézkedni. A kormány 1919. október 1-jén törvénypótló kormányrendelet ${ }^{8}$ alakjában hirdette ki a magyarországi rendőrségek államosítását,

\footnotetext{
3 Az eddig ismert rendőrségi sajtókiadványok összefoglaló bemutatásához lásd bővebben: Tóth Sándor: A rendőrség krónikásai - 140 év laptörténete. In Szomor Sándor (szerk.): Jubileumi Emlékalbum a 125 éve alakult Budapesti Detektívtestület tiszteletére. Budapest, Országos Rendőr-főkapitányság, 2011. 144-146.; Kriskó Edina: A Közbiztonságtól a Rendőrkutyáig - rendőrségi lapok a második világháborúig. Belügyi Szemle, 61. (2013), 1. 79-90.; Abonyi (2016) i. m.; Sallai János: A rendészeti folyóiratok hatása a rendészettudományra. Magyar Rendészet, 17. (2017), 2. $183-204$.

4 Egyedülálló kezdeményezésnek tekinthető az 1956 előtti rendészeti szaklapok kriminalisztikai vonatkozású cikkeinek bibliográfiai adattárba történő rendezése, amely kiváló forrásgyűjtemény az ilyen tárgyú kutatásoknak. Ld. bővebben: A magyar nyelvủ kriminalisztikai szakirodalom bibliográfiája. Budapest, Belügyminisztérium Országos Rendőrkapitányság, 1956.

Csepreghy Lajos: Az első félév. Visszapillantás lapunk félévi működésére. Rendốri Lapok, (1895), 17. 4.

Kriskó (2013) i. m. 79.

Borbély Zoltán - Kapy Rezső (szerk.): A 60 éves magyar rendőrség 1881-1941. Budapest, Halász Irodalmi és Könyvkiadó Vállalat, 1942. 50.

8 5047/1919. M. E. rendelet. A rendőrség államosítása.
} 
amely később az 1920. évi I. törvénycikkel nyert törvényhozási jóváhagyást. ${ }^{9}$ A magyar rendőrség további fejlődését alapjaiban meghatározó rendelet értelmében a törvényhatósági jogú és rendezett tanácsú városokban a rendőrhatósági jogokat a továbbiakban a m. kir. állami rendőrség gyakorolta, a rendőri szolgálatot pedig annak állami közegei látták el. Ezt a rendelkezést a belügyminiszter egyes községekre és községi csoportokra is kiterjeszthette. Az új szervezetbe a budapesti államrendőrség és a M. Kir. Határrendőrség is beolvadt, így az új elnevezésű „M. kir. állami rendőrség" egységes szervezetet alkotott. ${ }^{10}$

Az Osztrák-Magyar Monarchia idején megszülető egyes rendőri szaklapok közül három élte túl a történelem viharait, és folytatta működését 1919 őszétől: a Közbiztonság (Rendôri Lapok) (1907-1929; 1934-1939), a Rendőrségi Lapok (1914-1928) és a Detektív (1919-1923). Előbbi két újságnak elhivatott - a rendőrképzésben és saját működési területükön szaktekintélynek számító - rendőrtisztviselők alkották a szerkesztői gárdáját, míg a Magyarországi Nyomozó Tisztviselők Országos Egyesületének Detektív címủ hetilapja Benedek Andor hírlapíró, tapasztalt rendőri riporter szerkesztésében jelent meg. ${ }^{11} \mathrm{Az}$ említett folyóiratokon kívül a rendelkezésre álló rendőri szakirodalom széles választékát kínálta az 1915-ben létrehozott rendőrségi szakkönyvtár. Állománya a hivatalosan kiadott könyvek gyüjtése mellett részben ajándékozás, részben vásárlás útján gyarapodott. Az 1920-as évek végén már 1000 kötetet meghaladó, katalógussal rendelkező tekintélyes szakkönyvtárban megtalálhatóak voltak köz- és közigazgatásjogi szakkönyvek, a rendőrség intézményével, büntetőjoggal, bűnvádi perrendtartással és kriminalisztikával foglalkozó kötetek, törvényés rendeletgyüjtemények, lexikonok, szótárak és külföldi szakfolyóiratok. ${ }^{12}$

\section{A Rend megszületése}

1921. november 7-én a Belügyi Közlöny belügyminiszteri rendelet formájában, azonban Nádosy Imre országos rendőrfőkapitány aláírásával intézett felhívást „valamennyi törvényhatóság első tisztviselőjének, m. kir. államrendőrség valamennyi kerületi főkapitányának, budapesti m. kir. államrendőrség főkapitányának, valamennyi m. kir. csendőrkerületi parancsnokságnak és a m. kir. révfőkapitányságnak” A Rend címü szaknapilap előfizetése tárgyában. ${ }^{13} \mathrm{Az}$ 1920-as évek első fele a rendőrségnél az egységesítés jegyében telt. Az ezzel kapcsolatos többéves szervezőmunka a Magyar Királyi Állami Rendőrség szervezetét, intézményeit, jogkörét és személyzeti viszonyait

\footnotetext{
Ennek 10. §-a szerint: „A nemzetgyúlés az 1919. évi augusztus hó 7. napja óta az alkotmányos jogrend és a jogbiztonság helyreállítása végett alakult kormányok és tagjaik rendeleteinek érvényességét elismeri." 1920. évi I. törvénycikk. Az alkotmányosság helyreállítására irányuló rendelkezések.

10 5047/1919. M. E. rendelet.

11 Detektív. Világ, (1919), 53. 6.

12 A rendőri szakképzés ügye. Rendőr, (1929), jubileumi sz. 94.

13 91.640/1921. B. M. rendelet. „A Rend” című szaknapilap előfizetése.
} 
egyaránt érintette. Ezzel párhuzamosan a belügyminiszter az egyes fegyveres rendfenntartó testületek szorosabb centralizációját is keresztül kívánta vinni:

„Az állami és társadalmi rend fokozottabb védelmének szükségessége parancsolólag megköveteli, hogy a rendőri, rendészeti és közbiztonsági teendők ellátásával megbízott különálló szervek irányítása az eddiginél fokozottabb mértékben központosíttassék, és hogy a legfelsőbb állami akarat egységesen s a lehető leggyorsabban valósíttassék meg a különálló rendészeti szervekkel való közvetlen és a bürokrácia lassúbb formuláit élénkítő új kapcsolatok megteremtésével." ${ }^{14}$

Állásfoglalása szerint $A$ Rend hozzá benyújtott tervezete egybevágott a fent említett irányelvvel, hiszen a tervezett lap az állami és társadalmi rend, a közbiztonság és a nemzetvédelem körébe vágó minden fontos feladat „állandó felszínen tartását”, szükség szerinti továbbfejlesztését, a közbiztonsági szervek közötti megértő együttműködés előmozdítását és a hazafias szellem ápolását tűzte ki fő céljául. A belügyminiszter a felsoroltak mellett hézagpótló feladatként jelölte ki az induló lap számára a rendészet körébe vágó törvények és rendeletek magyarázatát, a rendőri hírek gyors közvetítését, a körözések, elfogatóparancsok és nyomozólevelek napi rendszerességű közlését, a külföldi szakirodalom ismertetését, továbbá a rendészeti vonatkozású társadalompolitikai kérdések (például a gyermekvédelem) megvitatását. Támogatásáról biztosította az új sajtóorgánumot, amelynek elrendelte előfizetését az államrendőrség, csendőrség és folyamrendészet hivatalai, továbbá a kirendeltségek, őrszobák és őrségek részére. ${ }^{15}$ Bár a rendelet szerint a tervezett lap hivatalos jelleget nem nyert, A Rend kiadásával egyidejüleg megszüntettek számos addigi rendőrségi és csendőrségi kiadványt: a belügyminisztérium által kiadott Rendőri Közlönyt, a budapesti államrendőrség főkapitányságának kiadásában megjelent Államrendőrséget és Bûnügyi Értesítôt, valamint a honvédelmi minisztérium kiadásában megjelent Csendőrségi Lapokat. 1925-ben A Rend egyik rövid híre szerint a különböző rendőri szaklapok (Magyar Detektív, Rendőrségi Lapok, Rendőrségi Szemle, Közbiztonság, Detektív Szemle) terjesztése körüli visszaélésekkel kapcsolatban a budapesti főkapitány kijelentette: ezek a sajtótermékek magánvállalkozások kiadásai, amelyek az államrendőrséggel mint hatósággal semmilyen kapcsolatban nem állnak, „e lapokra történő előfizetés-, valamint hirdetésgyűjtéseknél a rendőrségre való bármilyen hivatkozás visszaélés s az ily visszaélést elkövetőket, mint csalókat, rendőrnek kell átadni” ${ }^{16}$

\section{Baksa János, a lap alapítója}

A Rend főszerkesztője, Baksa János a budapesti államrendőrség legképzettebb tisztviselői közé tartozott, mivel több szolgálati ágban is dolgozott hosszabb-rövidebb ideig. Eredményes és sikerekben gazdag munkájának köszönhetően már az 1910-es

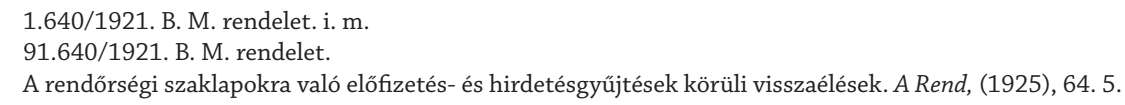


évek második felétől széles látókörű, nagy felkészültségú és komoly gyakorlati ismeretekkel rendelkező, elismert szakembere volt a rendőri testületnek.

Baksa János 1879-ben született Keszthelyen, középiskolai tanulmányait a premontrei főgimnáziumban végezte. Felsőfokú végzettségét a budapesti tudományegyetem jogi karán szerezte meg, ahol 1903-ban államtudományi államvizsgát tett. 1904-ben lépett a budapesti államrendőrség szolgálatába mint gyakornok. Fiatal rendőrfogalmazóként előbb a belvárosi kapitányságon, majd a VI. és az I. kerületi kapitányságokon, később a főkapitányság bủnügyi osztályának intellektuális csoportjában teljesített szolgálatot. Ezt követően a kihágási másodfokú rendőri büntetőbírósághoz került, amelynek rövidesen helyettes vezetője lett. Az I. világháború alatt írt cikkeiben feltárta, hogy annak befejeződésével a harcterekről hazaözönlő katonák és az előrelátható gazdasági válság miatt komoly öngyilkossági és bűnözési hullám várható, amelynek megelőzésére a rendőrségnek időben fel kell készülnie. ${ }^{17}$ Boda Dezső főkapitány a gondolatébresztő cikkek nyomán 1916-ban megbízta az ötletadó Baksa rendőrfogalmazót az öngyilkosvédő ügyosztály megszervezésével és vezetésével. Ezzel új, megelőző személetű, emberbaráti és szociális munkaterületet kapott a rendőrség. ${ }^{18}$ Baksa János a háború alatt a katonai kórházak élelmezése körül elkövetett visszaéléseket nyomozta, leleplezve egy erre szakosodott bünszervezetet, továbbá a hírhedt posztócsalási ügyben elsikkasztott pénz egy részére is ő talált rá. ${ }^{19}$ Sikereire felfigyelve 1917-ben a belügyminisztériumba rendelték, ahol kezdetben a személyzeti osztályon dolgozott, később szervezeti ügyekkel foglalkozott (több ügyviteli reformot és újítást megalkotva), ezután a közbiztonsági főosztályon dolgozott a moziügyek előadójaként, majd az 1919 után felállított internálási osztály vezetésével bízták meg, így ő volt a főnöke a zalaegerszegi, piliscsabai és csóti internálótáboroknak. Tíz évig teljesített szolgálatot a belügyminisztériumban, ezt követően a miniszter és Nádosy Imre országos rendőrfőkapitány javaslatára és kifejezett kérésére a budapesti rendőrség közigazgatási osztályának vezetését bízták rá. 12 éven át tartó hivatalában Baksa János szervezte meg a világvárossá fejlődött Budapest korszerű közlekedésrendészetét, annak minden részletére kiterjedő reformokat alkotva (egyebek mellett járdaszigetek felállítása, gyalogos-átkelőhelyek kijelölése, közlekedési rendőrség felállítása, kerékpárforgalom rendezése, a villamossínek utak közepére történő helyezése, egyirányú közlekedési rend megteremtése, közlekedési lámpák és jelzőkészülékek szaporítása, a gépjármúvek rendszámtábláinak megváltoztatása, helyszíni bírságolás bevezetése). A nagyívű program előkészületeként külföldi tanulmányútjai során látogatást tett Nyugat-Európa nagyvárosaiban, és az ott szerzett értékes tapasztalatait igyekezett a magyar viszonyokra alkalmazni. ${ }^{20}$ 1935-ben

\footnotetext{
7 Változás a Magyar Kir. Rendőrség vidéki főkapitánysága vezetésében. Magyar Rendôr, (1938), 14. 315.; Búcsúbeszélgetés a budapesti közlekedési rend megteremtőjével, Baksa János főkapitánnyal. Az Est, (1939), 176. 5.

18 Az ügyosztály felállítása bűnügyi rendészeti szempontból is jelentős volt, és később ebből fejlődött ki a rendőrség életvédelmi osztálya, amely 1928 nyarán kezdte meg múködését. Borbély-Kapy (1942) i. m. 141.; Öngyilkosjelöltek irodája. Pesti Napló, (1916), 347. 10.

19 Közszállítási emlékek. Honi Ipar, (1939), 17. 29.

20 Változás a Magyar Kir. Rendőrség vidéki főkapitánysága vezetésében (1938) i. m. 315.
} 
címzetesből valóságos főkapitány-helyettessé léptették elő. Rendőri pályája csúcsát 1938 nyarán érte el, amikor a belügyminiszter az államrendőrség második legfontosabb pozíciójának tekinthető vidéki főkapitánnyá nevezte ki. Pontosan egy évvel később, 35 éves szolgálatának fáradalmait maga mögött hagyva, saját kérelmére nyugállományba helyezték. A Magyar Rendőr méltató cikkében megemlékezett publicisztikai működéséről is: „»A Rend“ című szaklap felelős szerkesztői minőségében [...] irodalmi értékű vezércikkeiben éveken át a megalkuvást nem ismerő hazafiasság, keresztény és nemzeti érzés, fegyelmezettség és kötelességtudás igéit hirdette úgy, hogy azok a magyar közbiztonság minden harcosának lelkéhez utat találtak." ${ }^{21}$

\section{A szaklap hivatása, szerkezete és tartalma}

A Rend 1921. november 15-i első számában Baksa János így foglalta össze a lap küldetésnyilatkozatát:

„A Rend szerkesztőségének hite és meggyőződése, hogy olyan kulturális munkára vállalkozott, amely az egész múvelt világban eddig páratlan, mert egyetlen országnak sincs még olyan napilapja, amely a társadalmi rend őreit és a társadalmat egységbe, lelki harmóniába igyekszik foglalni [...] A Rend nagyarányú társadalmi és kulturális politikát fog folytatni, s miközben a legelevenebb és leggondosabb szaklapnak készül, egyben a nagyközönség szellemi és gyakorlati érdekeit is a leghathatósabban fogja előmozdítani." 22

Míg a többi fővárosi nagy napilap többek között az útjára induló új folyóirat politikamentességét is kiemelte, ${ }^{23} \mathrm{~A}$ Rend kimondottan a Bethlen-kormány politikai kurzusával egybevágó, nemzeti-konzervatív értékrendet képviselte, és az 1920-as évek kultúrpolitikáját „az állami és társadalmi együttműködés belső, lelki irredentizmusával szolgálja”. ${ }^{24}$

A folyóirat kezdetben hat oldalon jelent meg minden reggel, rotációs nyomdatechnikával. Felelős szerkesztőként Baksa János számított állandó vezércikkírónak, felelős szerkesztője Horváth István volt. A lap szerkesztősége és kiadóhivatala a IV. kerületi Magyar utca 3. szám alatt állt. A Rend, amely alcímében „rendészeti és társadalompolitikai napilapnak" nevezte magát, formátumának köszönhetően gyors hírszolgáltatást vezetett be, nagy hangsúlyt fektetve a rendészet körébe vágó rendeletek és törvények magyarázatára, emellett részletesen ismertette az országos jelentőségű napi eseményeket is. Az első oldalt mindig a szerkesztői vezércikk foglalta el, továbbá a rendészetet érintő hosszabb értekezés. A rendőrtisztikar és a közigazgatás

\footnotetext{
Baksa János vidéki főkapitány nyugalomban. Magyar Rendôr, (1939), 16. 363.

A magyar közönséghez! A Rend, (1921), 1. 1.

A Rend. 8 Órai Ujság, (1921), 261. 5.; Uj napilap. Nemzeti Ujság, (1921), 254. 6.

24 A politikamentességet cáfolja, hogy már a nyitószám a magyar politikai elit - gróf Bethlen István miniszterelnök, gróf Ráday Gedeon belügyminiszter, Ladik Gusztáv belügyi államtitkár és Tomcsányi V. Pál igazságügyminiszter - üdvözlő sorait és gondolatait tartalmazza.
} 
más szakíróin kívül $A$ Rend fennállása alatt 40 ismert nevű magyar írót és újságírót is foglalkoztatott. ${ }^{25} \mathrm{Az}$ 1921-1922-es évek ehhez bőven szolgáltattak alapanyagot, hiszen a rendőrség országos szervezése, az új szolgálati szabályzat megalkotása, a rendőrtisztviselők egységes rangsorának megállapítása, továbbá a rendőri szakoktatás tanfolyami rendszerben történő átalakítása mind a konszolidáció első éveiben indult el. A nyitóoldalt követték a fontosabb bel- és külpolitikai hírek, illetve az egyéb rendészeti szakcikkek és részletgazdag bünügyi tudósítások. A politika és a szaktudomány mellett külön szépirodalmi tárcák színesítették a lapot, amelyeket gyakran folytatásos formában közöltek. ${ }^{26} \mathrm{Az}$ 5. oldalt a mínuszos hírek (néhány mondatos rövid, vegyes tartalmú beszámolók) rovata foglalta el. A záróoldalon a színházi-múvészeti és a közgazdasági rovat osztozott. 1921 decemberétől a lap mellékleteiként jelentek meg a hivatalos jellegű közlemények (különböző minisztériumi rendeletekkel, kinevezésekkel, elveszett tárgyak listájával), illetve 1922 júliusától az újból elindított Bünügyi Körözések Lapja. ${ }^{27}$

A folyóirat 1922 januárjától négy oldal, majd februártól két oldal terjedelemre szükült, valószínúleg anyagi okok miatt. Ez eleinte csak rövid távú gondként jelentkezett, mivel a lap visszatért négyoldalas terjedelmére, 1922. július 2-án azonban a főszerkesztő szomorú hírt közölt: „Rajtunk kívül álló erők csavarják ki kezünkből a tollat, de még sem búcsúzunk, csak kénytelenek vagyunk harci szakaszunkat megrövidíteni a hét két napjára." ${ }^{28}$ A hetilapformátumra történő átállást a nyomdai és papírárak, és ebből fakadóan az előállítási költségek jelentős mértékű emelkedése indokolta. Kedvező változás volt, hogy az innentől fogva szerdán és szombaton megjelenő lap terjedelme nyolc oldalra bővült, az addig meglévő rovatok nevei némileg módosultak, illetve újak jelentek meg (A világ folyása; Sport; Budapesti bűnkrónika; Irodalom/Múvészet; A falunak; Regény). 1923-tól számottevően nőtt a külföldi híranyagok száma a kiterjedt európai tudósítóhálózat jóvoltából, amely Bécsből, Berlinből, Párizsból, Londonból és Rómából szállította a részletes színes híreket a „berlini tivornyafészkek, szépségesték veszedelmesen elfajul divatjáról, Baracs Géza, a párisi magyar kalandor szélhámosságairól, a párisi kokainjárványról [...] a rigai húszmilliós bélyeghamisítás, a bécsi bankjegylopás telepatikus nyomozásáról [...]”. ${ }^{29}$ Ugyanebben az évben a megdrágult, így nehezebben hozzáférhető magyar és külföldi szakkönyvek és folyóiratok ismertetésével is külön rovat foglalkozott. ${ }^{30}$

Fennállása alatt $A$ Rend a tudományszervezésben, az ismeretátadásban és az előremutató kezdeményezések népszerűsítésében is aktívan közreműködött. Az 1922-től országosan útjára induló különböző rendőrségi szaktanfolyamokkal párhuzamosan

\footnotetext{
Változás a Magyar Kir. Rendőrség vidéki főkapitánysága vezetésében (1938) i. m. 315.

Lásd például: A. Conan Doyle: A haldokló detektív kalandjai (I. rész). A Rend, (1921), 6. 1-3.

„A Rend” lett a hivatalos köröző-lap. A Rend, (1922), 136. 1-2.

Olvasóinkhoz! A Rend, (1922), 134. 1.

29 A Rend külföldi hírszolgálata. A Rend, (1923), 17. 5.; Érdekesség, hogy a külföldi beszámolók hatására egy alkalommal a budapesti rendőrség is megkísérelte a telepatikus nyomozást. Lásd: Telepatikus próbanyomozás Budapesten. A Rend, (1923), 42. 4.

30 Szakirodalom. A Rend, (1923), 44. 5.
} 
a folyóirat is számos, a rendőrképzés témájával foglalkozó szakcikket osztott meg olvasóival. Az 1925. év lapszámai például az alábbi írásokat közölték: A rendôrök társadalmi müvelése; A túligényelt kvalifikáció; A budapesti $m$. kir. rendörség rendörképzö iskolája; Miért kell detektívképzés?; A közbiztonsági közegek hivatásszerü kiképzésének szükségessége; Rendörtovábbképzés társadalmi úton. A szakmai-tudományos értekezések, jogi kérdések fejtegetése mellett olyan gyakorlatias témák is napirendre kerültek benne, mint a rendőri testnevelés kérdése. A világháborút követően a testnevelés népszerűsítésére európai mozgalom szerveződött, ennek Magyarországra gyakorolt hatása a 1921. évben hozott testnevelési törvény kiadásában mutatkozott meg. A közegészség javítása és a „nemzet munkaerejének gyarapítása” érdekében a törvény 21 éves korig a nemzet minden férfitagja részére kötelezően előírta a rendszeres testnevelésben való részvételt, továbbá állami támogatásban részesítette azokat a társadalmi alakulatokat, amelyek „testneveléssel komolyan foglalkoznak s müködésük nemzeti irányával a támogatást megérdemlik". ${ }^{31}$ A rendőrtisztviselők önszerveződésében, ebben az évben megalakult a Budapesti M. Kir. Rendőrség Tisztikarának Atlétikai Clubja, rövidebb nevén Rendőrtiszti Atlétikai Club (RAC), majd 1925-ben a rendőrsport másik képviselője, a Detektív Atlétikai Club (DAC). Marinovich Jenő főkapitány a RAC ügyét felkarolva, napiparancsban hívta fel a tisztikart a klubba való belépésre. A két sportegyletben egymás után alakultak meg a vívó-, evező- és teniszszakosztályok. ${ }^{32}$ A rendőrlegénység testedzési lehetőségei azonban meglehetősen szűkre szabottak voltak, figyelembe véve a szolgálati beosztás nehézségét, az életkori különbségeket, valamint a rendőrök szétszórt elhelyezését. $A$ Rend egyes tárcái 1923-tól kezdve irányították rá a nyilvánosság figyelmét az intézményes rendőri testnevelés kérdésére, a fizikai erő és a testi ügyesség meghatározó szerepére a szolgálat során alkalmazott intézkedésekben. ${ }^{33}$ A sport tárgykörével foglalkozó cikkek szolgáltak alapjául annak, hogy A Rend tudományos múhelyként, szakmai vitafórumként is elkezdett működni a különböző időszerű rendészeti kérdések megvitatásához. 1923. március 10-ei számában a folyóirat addig szokatlan módon felhívást intézett olvasóihoz: „Miként oldható meg a rendőri testnevelés kérdése a legrövidebb idő alatt? Minél több az eszme pártolója, minél nagyobb lesz azok száma, akik az eszme mellett lándzsát törnek, annál eredményesebb lesz a munka és annál hamarább valósul meg a gondolat." ${ }^{34}$ December 15-én a lap már pénzdíjas pályázatot hirdetett a rendőr szolgálatát és magánéletét tárgyaló cikkekre, 1924-ben a cselédkérdést, 1925-ben pedig a rendőri büntetőeljárás egyszerűsítését és a rendőri külső szolgálat kisebb városokban való ellátását tette pályázat tárgyává. ${ }^{35} \mathrm{~A}$ bárki által beküldhető, név nélküli, jeligés pályamunkákat komoly szakemberek: az államrendőrség országos szaktanulmányi felügyelője, parancsnoka és egyik tanára bírálták el. Az első

\footnotetext{
1921. évi LIII. törvénycikk a testnevelésről.

Borbély-Kapy (1942) i. m. 289-291.

Rendőr-atlétika. A Rend, (1923), 16. 7.; Rendőrsport. A Rend, (1923), 29. 6.

Rendőratlétika. A Rend, (1923), 20.6.

Dorning Henrik: „A Rend” és a rendőri szakoktatás. A Rend, (1926), 92-93. 5.
} 
pályázat díjazottjai között volt dr. Szőllősy Alfréd belügyminisztériumi segédtitkár, dr. Griczman Gyula szombathelyi rendőrkapitány és Barna Tibor rendőr-főfelügyelő. A névsorból látható, hogy a rendőrség magas rangú tagjai is képviselték magukat tudományos-szakmai értekezéseikkel. ${ }^{36}$ A bírálóbizottság elnöke, dr. Dorning Henrik a rendőri szakoktatás fontos támaszaként méltatta a folyóiratot, amely lehetőséget biztosított a fiatal rendőrgeneráció tagjai számára hallatni hangjukat:

„A rendőri szaklapot sem szabad aszerint megítélni, hogy egyik vagy másik száma mit hoz újat nekem, az egyes olvasójának, hanem azt kell néznünk, mit jelent meglétével, számai egész sorának tartalmával mások és az összesség, a rendőrség egésze számára. Nemcsak az a fontos, hogy a már megérkezettek, a már elismert nevúek írjanak rendőri szakcikkeket, hanem az is, hogy akit »hajt a lélek«, akinek nagy a kedve, hozzá merjen fogni a gondolatainak formábaöntéséhez s alkalmat kapjon arra, hogy első cikkeivel a kartársak színe elé léphessen [...] Utódok kellenek, fiatal szakírógárda, amelynek mindazt meg kell tennie, mindazt kell pótolnia, amit mi elmulasztottunk."37

Ilyen fiatal tehetség volt Unger Jenő, a diósgyőr-vasgyári rendőrkirendeltség fogalmazója is, akinek Elfogult bünösök című terjedelmes kriminálpszichológiai tanulmánya 1925-ben A Rend közlésében jelent meg. Az írás tartalmi feldolgozásánál fogva felkeltette a belügyminisztérium érdeklődését is, és egyhangúan szavazták meg bemutatásra a New Yorkban tartandó rendőrségi világkongresszus magyar delegációjában. Alig egy hónappal a tanulmány megjelenése után két külföldi kiadócég is felkereste Ungert írásának német és francia nyelvre történő lefordításának jogaiért. ${ }^{38}$

\section{A Rendhez köthető egyéb kiadványok}

A Rend című folyóirat az azonos nevű kiadóvállalat égisze alatt múködött, és fennállása során két úttörő rendőrségtörténeti kötetet tett közzé, amelyek alapjául szolgáltak a rendőrség múltjával kapcsolatos későbbi kutatásoknak. 1922. november 22-én a M. Kir. Állami Rendörség országos szaktanfolyamainak megnyitóján Dorning Henrik fökapitány-helyettes, szaktanulmányi felügyelő tudományos előadással felérô ünnepi beszédét teljes terjedelemben közölte a Rend 177. és 178. száma, amelyet később füzet alakú különlenyomatként is kiadtak, és hosszú éveken keresztül tananyagként szolgált a rendőrhallgatóknak. ${ }^{39}$ 1923-ban, a budapesti államrendőrség fennállásának 50 éves jubileuma alkalmából az akkor már rendőrfőtanácsos Baksa János főszerkesztő A Rend kiadásában egy egyedülálló és úttörő szakmunkában dolgozta fel az intézmény történetét, amelyből több részletet előzetesen már a folyóirat is közölt. Az 544 oldalas, díszes kiállítású, illusztrált Rendőrségi Almanach - amely nevével ellentétben nem

\footnotetext{
A Rend pályázatának eredménye. A Rend, (1924), 15. 5.

37 Dorning (1926) i. m. 5.

38 Unger Jenő rendőrfogalmazó tanulmánya a newyorki rendőrkongresszuson. Magyar Jövő, (1925), 101. 5.

39 Dorning Henrik: A rendôrség intézményének fejlődése. Különös tekintettel a Magyar Királyi Állami Rendôrségre és a magyar rendöri szakoktatásra. Budapest, Budapesti Hírlap Nyomda, 1922.
} 
pusztán évkönyvjellegű volt - az addigi legjobb összefoglalását nyújtotta a fővárosi rendőrség történetének. Az 1918-ig tartó időszak Vécsey Leó szerkesztésében olvasható, Baksa János pedig az őszirózsás forradalom óta eltelt öt esztendőt ismerteti. Dorning Henrik külön fejezetben, 40 oldalon írta meg a vidéki rendőrségek államosításának folyamatát. Az almanach nevéhez húen bemutatja az 1923-ban múködő országos testület szervezetét, és listaszerűen közli is a budapesti főkapitányság és a vidéki kerületi főkapitányságok személyzetének teljes névsorát. A könyv gazdag szépirodalmi résszel zárul, amely különböző elbeszéléseket, verseket és történeti viszszapillantásokat tartalmaz, többek között Rákosi Jenő, Herczeg Ferenc, Móricz Zsigmond, Cholnoky László, Szathmáry István és Tábori Kornél tollából. ${ }^{40}$

\section{A Rend megszúnése}

1927. június 29-én a szaklap vezércikkében búcsúzott olvasóitól:

„Nehéz időkben vállalkoztunk nehéz szerepünkre. Kezünkbe vettük a zászlót, igyekeztünk mentől magasabbra tartani, megőrizni, sártól, szennytől. A közrend ellenségei ellen vívott csatákban a szellem fegyvereivel állandóan az első sorokban küzdöttünk. A közbiztonsági szervek fegyvertárát, harci eszközeit tökéletesíteni törekedtünk [...] Felemelt fővel tesszük le ezt a zászlót a rendőrség múzeumába azzal az elszomorító tudattal, hogy a rendőri szakirodalom, de a nemzeti sajtó is újra szegényebb lett egy harci lobogóval." ${ }^{\prime 1}$

A főszerkesztő $A$ Rend megszűnését szűkszavúan egy közelebbről nem részletezett belügyminiszteri rendeletnek tulajdonította. A napilapok először tévesen egy, a rendőri étkezde körül kialakult sikkasztási ügyet, és ennek következtében a különböző rendőrségi „jóléti üzemek” fokozatos megszüntetését sejtette a háttérben, azonban állításaikat később tisztán pénzügyi és technikai okokra módosították. ${ }^{42}$ A Rend utódlapjának számító, Markovich Miklós rendőrtanácsos szerkesztésében hetente megjelenő Rendőr és a Magyar Detektív szerint a rendőrség és a csendőrség külön-külön folyóirat elindítását határozta el, és ennek megfelelően a Rendőr és az újból kiadandó Csendőrségi Lapok egymástól függetlenül folytatják működésüket. ${ }^{43}$

\section{FELHASZNÁLT IRODALOM}

Abonyi Magdolna: A magyar rendőri szaksajtó kezdetei: a Közbiztonság. Magyar Rendészet, 16. (2016) 6. 155-168.

\footnotetext{
40 Baksa János (szerk.): Rendőrségi Almanach. Budapest, A Rend kiadása, 1923. 543-544.; Az ötvenéves államrendőrség. Budapesti Hírlap, (1923), 141. 4-5.

41 Búcsúzó. A Rend, (1927), 52. 1.; Olvasóinkhoz. A Rend, (1927), 52. 5.

42 A „Rend” megszüntetésének ügye. Pesti Hírlap, (1927), 149. 11.

43 Búcsú és beköszöntő. Rendôr, (1927), 1. 7.; Rendőr. Markovich Miklós dr. rendőrtanácsos új rendőri szakhetilapja. Magyar Detektív, (1927), 15. 4.
} 
A magyar nyelvü kriminalisztikai szakirodalom bibliográfiája. Budapest, Belügyminisztérium Országos Rendőrkapitányság, 1956.

A magyar közönséghez! A Rend, (1921), 1. 1.

A Rend. 8 Órai Ujság, 1921. 261. 5.

A Rend külföldi hírszolgálata. A Rend, (1923), 17. 5.

„A Rend” lett a hivatalos köröző-lap. A Rend, (1922), 136. 1-2.

A „Rend” megszüntetésének ügye. Pesti Hirlap, (1927), 149. 11.

A rendőri szakképzés ügye. Rendör, (1929), jubileumi sz. 94.

A rendőrségi szaklapokra való előfizetés- és hirdetésgyűjtések körüli visszaélések. A Rend, (1925), 64.5.

A Rend pályázatának eredménye. A Rend, (1924), 15. 5.

Az ötvenéves államrendőrség. Budapesti Hírlap, (1923), 141. 4-5.

Baksa János (szerk.): Rendőrségi Almanach. Budapest, A Rend kiadása, 1923.

Baksa János vidéki főkapitány nyugalomban. Magyar Rendôr, (1939), 16. 363.

Borbély Zoltán - Kapy Rezső (szerk.): A 60 éves magyar rendőrség 1881-1941. Budapest, Halász Irodalmi és Könyvkiadó Vállalat, 1942.

Búcsúbeszélgetés a budapesti közlekedési rend megteremtőjével, Baksa János főkapitánnyal. Az Est, (1939), 176. 5.

Búcsú és beköszöntő. Rendôr, (1927), 1. 7.

Búcsúzó. A Rend, (1927), 52. 1.

Csepreghy Lajos: Az első félév. Visszapillantás lapunk félévi működésére. Rendốri Lapok, (1895), 17. 4.

Detektív. Világ, (1919), 53. 6.

Dorning Henrik: A rendörség intézményének fejlödése. Különös tekintettel a Magyar Királyi Állami Rendôrségre és a magyar rendőri szakoktatásra. Budapest, Budapesti Hírlap Nyomda, 1922.

Dorning Henrik: „A Rend” és a rendőri szakoktatás. A Rend, (1926), 92-93. 5.

Doyle, A. Conan: A haldokló detektív kalandjai (I. rész). A Rend, (1921), 6. 1-3.

Közszállítási emlékek. Honi Ipar, (1939), 17. 29.

Kriskó Edina: A Közbiztonságtól a Rendőrkutyáig - rendőrségi lapok a második világháborúig. Belügyi Szemle, 61. (2013) 1. 79-90.

Olvasóinkhoz! A Rend, (1922), 134. 1.

Olvasóinkhoz. A Rend, (1927), 52. 5.

Öngyilkosjelöltek irodája. Pesti Napló, (1916), 347. 10.

Rendőratlétika. A Rend, (1923), 20.6.

Rendőr-atlétika. A Rend, (1923), 16. 7.

Rendőr. Markovich Miklós dr. rendőrtanácsos új rendőri szakhetilapja. Magyar Detektív, (1927), 15. 4.

Rendőrsport. A Rend, (1923), 29. 6.

Sallai János: A rendészeti folyóiratok hatása a rendészettudományra. Magyar Rendészet, 17. (2017), 2. 183-204.

Szakirodalom. A Rend, (1923), 44. 5.

Telepatikus próbanyomozás Budapesten. A Rend, (1923), 42. 4.

Tóth Sándor: A rendőrség krónikásai - 140 év laptörténete. In Szomor Sándor (szerk.): Jubileumi Emlékalbum a 125 éve alakult Budapesti Detektivtestület tiszteletére. Budapest, Országos Rendőrfőkapitányság, 2011. 144-146.

Uj napilap. Nemzeti Ujság, (1921), 254. 6.

Unger Jenő rendőrfogalmazó tanulmánya a newyorki rendőrkongresszuson. Magyar Jövő, (1925), 101. 5.

Változás a Magyar Kir. Rendőrség vidéki főkapitánysága vezetésében. Magyar Rendőr, (1938), 14. 314-315. 


\section{Jogforrások}

5047/1919. M. E. rendelet. A rendőrség államosítása

1920. évi I. törvénycikk. Az alkotmányosság helyreállítására irányuló rendelkezések

1921. évi LIII. törvénycikk a testnevelésről

91.640/1921. B. M. számú rendelet. „A Rend” címú szaknapilap előfizetése

\section{ABSTRACT}

The First Daily Journal of the Hungarian Police: A Rend (The Order) (1921-1927) Gábor ANDROVICZ

In the course of the police history research, due to their value as sources, the various professional periodicals, typically controlled and published by the given armed force, are not negligible. The Rend, is considered the first representative of the police journals operating between the two world wars, which followed the development of the body as a contemporary of the Royal Hungarian State Police, was becoming national. As a professional forum, it gave place for the polemics about the inner organisation of the police, and participated actively in the support of the vocational training, the value of mediation and the progressive initiatives. The paper introduces the circumstances of the journal's start, its structure, the forming of the main content characteristics and its role in the contemporary law enforcement.

Keywords: history of journalism, journal, A Rend, police history 